\title{
ENTREVISTA COM KENNETH DAVID JACKSON
}

\author{
INTERVIEW WITH KENNETH DAVID JACKSON
}

\author{
Por: Cynthia Beatrice Costa ${ }^{1}$ \\ Andréia Guerini ${ }^{2}$
}

Traduzida para o inglês por Cynthia Beatrice Costa

\footnotetext{
${ }^{1}$ Doutora em Estudos da Tradução (2016) pela Universidade Federal de Santa Catarina (UFSC). Mestre em Literatura e Crítica Literária (2008) pela Pontifícia Universidade Católica de São Paulo (PUC - SP). Graduada em Jornalismo (2002) pela Faculdade Cásper Líbero. Professora na Universidade Metodista de Piracicaba (UNIMEP). Piracicaba, São Paulo, Brasil. E-mail: cynthia_costa@uol.com.br

2 Doutora em Literatura pela UFSC e pós-doutorado pela Università degli Studi di Padova. Desde 2011, atua como professora visitante do programa de Doutorado em Letteratura, Storia della Lingua e Filologia Italiana da Università per Stranieri di Siena/Itália. É professora associada do Departamento de Língua e Literatura Estrangeiras DLLE e da Pós-Graduação em Estudos da Tradução da Universidade Federal de Santa Catarina PGET (UFSC). Florianópolis, Santa Catarina, Brasil. E-mail: andreia.guerini@gmail.com
} 


\section{ENTREVISTA COM KENNETH DAVID JACKSON}

Kenneth David Jackson ${ }^{3}$ é hoje um dos principais responsáveis pela disseminação da obra de Joaquim Maria Machado de Assis (1839-1908), e também de modernistas brasileiros, em língua inglesa. Texano formado em música, além de literatura, é atualmente diretor da graduação em Estudos do Português na Universidade de Yale/EUA.

Jackson vem publicando, ao longo dos anos, trabalhos a respeito das literaturas brasileira e portuguesa, sobretudo a de vanguarda, e sobre a presença da cultura portuguesa em países asiáticos, como em De Chaul a Batticaloa: As Marcas do Império Marítimo Português na Índia e no Sri Lanka (2005). A obra de Camões, Pessoa, Mário de Andrade, Oswald de Andrade e Patrícia Rehder Galvão, a Pagu, estão entre os seus principais interesses - estes motivados, ainda, pela amizade duradoura que Jackson manteve com alguns dos mais prolíferos intelectuais brasileiros, como os críticos literários Benedito Nunes (1929-2011) e Haroldo de Campos (1929-2003).

É em Machado de Assis, no entanto, que se concentra o seu fascínio. Em 2006 organizou a Oxford Anthology of the Brazilian Short Story, na qual incluiu 10 contos do autor. Em 2015, publicou um longo estudo sobre o fundador da Academia Brasileira de Letras, Machado de Assis: A Literary Life, propondo uma visão marcadamente psicológico-filosófica de seus romances. Esse já pode ser

\footnotetext{
${ }^{3}$ Professor no Departamento de Espanhol e Português da Yale University, EUA, onde é diretor do programa de graduação em Estudos Portugueses. Tem interesse pelas literaturas e culturas brasileira e portuguesa. New Haven, Connecticut, EUA. E-mail: k.jackson@yale.edu
} 
considerado um dos mais importantes trabalhos publicados nos Estados Unidos a respeito do autor brasileiro, dando continuidade à herança crítica deixada por Helen Caldwell, que revolucionou a interpretação de Dom Casmurro (1899) com o ensaio The Brazilian Othello of Machado de Assis (traduzido no Brasil como $O$ Otelo Brasileiro de Machado de Assis), em 1960, e reuniu detalhes inéditos até para pesquisadores brasileiros em Machado de Assis: The Brazilian Master and His Novels, de 1970. Não à toa, Caldwell é a tradutora anglófona de Machado de Assis que Jackson mais admira, como ele afirma na entrevista a seguir. Esta aborda, ainda, a presença da filosofia na obra machadiana e, entre outros assuntos.

Revista da Anpoll (RA): Como começou o seu grande interesse por Machado de Assis?

Kenneth David Jackson (KDJ): Na verdade, comecei a ler Machado quando ainda era aluno de graduação, época em que apenas começava a estudar português.

RA: Que teóricos mais influenciaram a sua visão a respeito da obra machadiana?

KDJ: Primeiro, o ensaio de Benedito Nunes, "Machado de Assis e a filosofia"; José Barreto Filho (Introdução a MA, 1947); Agrippino Grieco (MA, 1960); Eloy Pontes (A contradição em MA, 1939; Augusto Meyer (introdução à exposição centenária, 1939); Helen Caldwell (os dois livros e ensaios). Também Charles Rosen (Classical Style); Jorge de Sena e Vítor Aguiar e Silva (sobre Camões e melancolia); e Walter Krysinski (texte hybride). Também João R. Faria e Galante de Sousa (teatro); André Heller-Lopes e Carlos Whers (música).

RA: De todos esses, qual consideraria ter sido o mais decisivo?

KDJ: Helen Caldwell, uma grande estudiosa de Machado, especialista em latim e grego, e em cultura clássica. Ela logo percebeu o mundo de referências que subjaz a obra machadiana.

RA: Na introdução de Oxford Anthology of the Brazilian Short Story (2006), você oferece um vasto e aprofundado panorama de toda a história literária brasileira. Quais momentos você considera decisivos para a formação da nossa identidade literária?

KDJ: Todos. Apesar da utilidade de uma visão sincrônica e seletiva para compor uma história, não é desejável descaracterizar o caráter evolutivo e sequencial da formação de uma grande literatura de meio milênio. Dito isto, acho importante ressaltar a importância do barroco, estilo dominante do império luso e do Brasil colônia por mais de três séculos, com obras expressivas da língua, sociedade, do comportamento e dos costumes desta terra. 
RA: Na mesma introdução, você afirma que os temas éticos e morais e uma visão filosófica do mundo estão entre os mais recorrentes do gênero contista brasileiro.

KDJ: Certamente, os contos na antologia são muito expressivos de temas éticos, filosóficos e psicológicos. Nada mais humano do que "João Urso", de Breno Accioly; o narrador de "O Peru de Natal", de Mário de Andrade; o enfrentamento da questão da paixão em "O Búfalo", da Clarice Lispector; ou da pobreza que desvia o raciocínio na tragicomédia "O Ladrão", de Graciliano Ramos.

RA: Falando em Mário de Andrade, você estuda os modernistas brasileiros com afinco. De que maneira acredita que Machado se relaciona com o Modernismo?

KDJ: Acho que Machado não se relaciona com o modernismo, é o modernismo que tem de se relacionar com ele, resolver o que fazer com o seu enorme legado. De maneira geral, evita-se o contato, mas há continuidades, como, por exemplo, nas Memórias Sentimentais de João Miramar, de Oswald de Andrade, que é como um Brás Cubas modernista que finge inocência ao relatar as suas aventuras retrospectivamente. Os contos do Mário de Andrade também desvendam problemas sociais e psicológicos, mas com uma estrutura narrativa diferente.

RA: Há quem defenda, como Haroldo de Campos, que Machado tenha se relacionado com o cânone inglês - com destaque para Laurence Sterne - de maneira antropofágica, "digerindo" o que lhe interessava importar para a nossa literatura. Você concorda com essa noção?

KDJ: Essa ideia - lembrando-se que não foi Haroldo que primeiramente fez a ligação de Machado com Sterne -, como diria Brás Cubas, é apenas uma meia-verdade, se isto. Sterne não é o pai das borboletas. Reparamos, na leitura de Machado, como autor se refere constantemente a uma verdadeira "biblioteca mundial", da qual "digere" e incorpora à sua maneira estilos, ideias e temas. Acho que não se trata de "importação", precisa-se de outra palavra. Ele faz uma síntese do panorama de ideias e obras acessíveis a qualquer leitor, que caracterizam a psicologia e o comportamento humanos tanto no Brasil como em qualquer cultura, com as devidas adaptações. A novidade talvez seja a intensidade da síntese e da arte de citação.

RA: $O$ mesmo poderia ser dito em relação a outros autores do cânone ocidental?

KDJ: Os autores sempre têm múltiplas influências, das suas leituras, mas talvez não de uma "biblioteca mundial", ideia ligada ao Iluminismo. Joyce, por exemplo, estruturou Ulysses a partir dos episódios da Odisseia. 
RA: Como você vêldescreveria a relação de Machado com autores italianos, em especial com Giacomo Leopardi?

KDJ: Segundo Grieco, todo o episódio do "Delírio" (capítulo 7 das Mémorias Póstumas) veio de Leopardi, do "Dialogo di un islandese". Dante, nem se fala, é a base de Esau e Jacó.

RA: Você afirma, em Machado de Assis: A Literary Life (2015), que Machado criou um mundo filosófico. Como isso se dá na trajetória literária dele?

KDJ: Benedito Nunes mostra nesse ensaio como Machado é sempre filosófico, mas, ao mesmo tempo, zomba da filosofia, ficando distante da adoção de qualquer postulado. Prefere considerar o fluxo das ideias e as suas mudanças, as adaptações com o tempo.

RA: "Ele é um moralista racional em busca de sabedoria por meio do seu teatro do mundo" (2015, p. xii). Poderia comentar essa afirmação?

KDJ: Machado põe no palco um mundo barroco, do Império e das estruturas sociais e psicológicas atendentes; observa e critica com ideias iluministas, encontradas no mundo da razão, aproveitando-se muitas vezes de máximas e provérbios tão ao gosto dos franceses, como Rochefoucauld, Diderot e La Fontaine.

RA: A relação de Machado e a criação de um mundo filosófico teria relação com autores italianos?

KDJ: Acho que tem mais a ver com a leitura dos gregos.

RA: O que seria a "retórica da dissimulação e substituição" machadiana?

KDJ: Machado escreve muitas vezes a partir de objetos simbólicos, que em si dissimulam o seu objetivo verdadeiro. Substituem, nesse sentido, uma descrição mais discursiva de determinada situação.

RA: Ainda no livro, você pontua que Machado teria escrito por "razões profundamente literárias". Quais seriam essas razões? Têm relação com a opção pelo subtitulo do livro, "A Literary Life"?

KDJ: O título não era meu, era do editor. Eu teria chamado o livro de "o teatro do mundo". E preciso ressaltar que a palavra-chave do título é "Literary" e não "Life", pois não pretende ser uma biografia. Pretende investigar os fundamentos literários do seu pensamento, que têm muito a ver com as suas vastas leituras e, também, com o teatro e a ópera, tão importantes na sua experiência enquanto jovem e também nos seus romances. 
RA: Como se dá, na sua opinião, a relação entre o Rio de Janeiro machadiano, tão presente e característico nas obras do autor, e as influências europeias igualmente presentes em seus livros?

KDJ: Acho que o Brasil também faz parte do "universal", não acho muito útil essa terminologia. Não seria o caso pensar nas viagens, que através do tempo formaram a cultura brasileira, em grande parte? O "cá e lá" da "Canção do Exílio" de Gonçalves Dias. Parece mais o caso de uma simbiose do que de uma "influência", a não ser que se acredite na singularidade brasileira, pré-cabraliana, que depois sofreu "influências".

RA: Você tem preferência pelo trabalho de algum tradutor anglófono de Machado de Assis? Por quê?

KDJ: Gosto muito, ainda, das traduções de Helen Caldwell, mas também as Memórias Póstumas de William Grossman e o Quincas Borba de Clotilde Wilson. Há novas traduções, mas teria sido mais interessante fazer traduzir obras ainda não traduzidas do que traduzir novamente o já traduzido.

RA: Machado de Assis já pode ser considerado uma influência literária além das fronteiras lusófonas? De que forma?

KDJ: Está tendo mais impacto, mas avança devagar. Por exemplo, Carlos Fuentes escreveu Machado de la Mancha. Existe agora uma excelente crítica de Machado de Assis de Paul Dixon. E Harold Bloom fez o seu tanto ao incluir Machado na lista de autores fundamentais da literatura ocidental. Falta ainda a difusão da nova crítica, falta incorporar Machado no cânone da literatura comparada, falta de maneira geral ler Machado.

RA: Machado de Assis é o autor brasileiro mais estudado fora do Brasil, segundo uma pesquisa do Itaú Cultural de 2013. Você sente um interesse sólido por Machado na academia estadunidense?

KDJ: Esse "mais estudado", de que consiste? Há apenas 11.000 alunos de língua portuguesa nos EUA, que têm uma população de 300 milhões de habitantes. Alguns alunos "ouviram falar", mas poucos leram e acredito que ainda menos "pegaram" alguma coisa. Infelizmente, não existe ainda esse interesse "sólido" por Machado, ou por qualquer outro autor brasileiro. 


\section{INTERVIEW WITH KENNETH DAVID JACKSON}

Traduzida por

Cynthia Beatrice Costa

Kenneth David Jackson is currently one of the main responsible for spreading the work of Joaquim Maria Machado de Assis (1839-1908), as well as of Brazilian modernists, in English. A Texan who graduated in Music, in addition to Literature, he is now director of Director of Undergraduate Studies for Portuguese at Yale University.

Through the years, Jackson has been publishing books and articles regarding Brazilian and Portuguese literatures, especially avant-garde works, and on the presence of Portuguese culture in Eastern countries, such as in De Chaul a Batticaloa: As Marcas do Império Marítimo Português na Índia e no Sri Lanka (2005). The works of Camões, Pessoa, Mário de Andrade, Oswald de Andrade and Patrícia Rehder Galvão, also known as "Pagu", are among his main interests - which are also motivated by the lasting friendships he cultivated with some of the most prolific of Brazilian intellectuals, such as Benedito Nunes (1929-2011) and Haroldo de Campos (1929-2003).

His fascination, however, is concentrated on Machado de Assis. In 2006, he organized the Oxford Anthology of the Brazilian Short Story, which includes 10 short stories by the author. In 2015, he published a long study about the founder of the Brazilian Academy of Letters, Machado de Assis: A Literary Life, in which he proposes a psychological-philosophical reading of his novels. This can already be considered one of the most relevant works published in the United States about the Brazilian author, continuing the legacy left by Helen Caldwell, who revolutionized the traditional interpretation of Dom Casmurro (1899) with her essay The Brazilian Othello of Machado de Assis in 1960 and gathered never known - even by Brazilian researchers - details in Machado de Assis: The 
Brazilian Master and His Novels, in 1970. It is not for nothing that Caldwell is Jackson's favorite Anglophone translator of Machado de Assis's works, as he states in the following interview. It approaches the presence of philosophy in the Machadian body of work as well, among other topics.

Revista da Anpoll (RA): How did your great interest in Machado de Assis start?

Kenneth David Jackson (KDJ): I actually started to read Machado when I was an undergraduate student and was only beginning to learn Portuguese.

RA: What scholars had the most influence on your vision about Machado's work?

KDJ: Firstly, Benedito Nunes's essay, "Machado de Assis e a filosofia" (Machado de Assis and the Philosophy); José Barreto Filho, Introdução a Machado de Assis (Introduction to Machado de Assis, 1947); Agrippino Grieco (Machado de Assis, 1960); Eloy Pontes, A contradição em Machado de Assis (The Contradiction in Machado de Assis, 1939); Augusto Meyer, his introduction to Machado de Assis's centennial exposition (1939); Helen Caldwell (her two books and essays). Also, Charles Rosen (Classical Style); Jorge de Sena and Vítor Aguiar e Silva (about Camões and melancholy); and Walter Krysinski (texte hybride). Lastly, João R. Faria and Galante de Sousa (theater); André HellerLopes and Carlos Whers (music).

RA: From all these, which one would you say was the most crucial?

KDJ: Helen Caldwell, the great master in the study of Machado, specialist in Latin and Greek and in Classical Culture. She soon realized the world of references that underlies Machadian works.

RA: In the introduction of the Oxford Anthology of the Brazilian Short Story (2006), you offer to the reader a vast and in depth overview of the history of Brazilian literature. What moments do you consider were decisive to the formation of our literary identity?

KDJ: All of them. Even though a synchronic and selective vision may be useful to compose history, it is not desirable to decharacterize the evolutionary and sequential character of the formation of a great literature that is half a millennium old. Having said that, I think it is relevant to emphasize the importance of the Baroque, which was the dominant style in the Portuguese Empire and in Colonial Brazil for more than three centuries, with expressive works involving language, society, behavior and habits of the land. 
RA: Still in that introduction, you affirm that ethical and moral themes, in addition to a philosophical view of the world, are among the most frequent in the Brazilian short story style.

KDJ: Certainly, the short stories compiled in the anthology are very expressive in what concerns ethical, philosophical and psychological themes. Nothing more human than "João Urso", by Breno Accioly; the narrator of "The Chistmas Turkey", de Mário de Andrade; the tackling of the passion in "O Buffalo", by Clarice Lispector; of the poverty that diverts reasoning in the tragicomedy "O Thief”, by Graciliano Ramos.

RA: Talking about Mário de Andrade, you study Brazilian modernists with endeavor. In what way do you think Machado's work can be associated with the Modernism?

KDJ: I don't think that his work can be associated with Modernism, it is the Modernism that should be associated to his work. It had to decide what to do with his enormous legacy. In general, this contact is avoided, but there are continuities, for example, in the Memórias Sentimentais de João Miramar, by Oswald de Andrade, who is a Modernist Brás Cubas pretending innocence as he relates his adventures retrospectively. Mário de Andrade's short stories also uncover social and psychological problems, but with a different narrative structure.

RA: There are those who defend, like Haroldo de Campos, that Machado had an anthropophagical relationship with the English canon - especially with Laurence Sterne -, "digesting" what he wanted to import into our literature. Do you agree with this notion?

KDJ: This idea - and it should be remembered that it wasn't Haroldo who first suggested a link between Machado and Sterne -, as Brás Cubas would say, it a half-truth, maybe not even that. Sterne is not the "father of butterflies". We may notice, while reading Machado, how he makes constant reference to a true "world library", from which he "digests" and incorporates in his own fashion styles, ideas, and themes. I don't think it is an "import", we would need another word. He makes a synthesis of the ideas and works that are accessible to any reader, which characterize human psychology and behavior in Brazil and in any other culture, save for some adaptations. The novelty is probably the intensity of this synthesis and of the art of quotation.

RA: Could the same be said about other authors from the Western canon?

KDJ: Authors always receive multiple influences from their readings, but maybe not from a "world library", an idea that is related to the Enlightenment. Joyce, for instance, structured Ulysses based on the episodes of the Odyssey. 
RA: How do you see the relation of Machado with Italian writers, especially with Giacomo Leopardi?

KDJ: According to Grieco, the whole episode of the "Delirium" (chapter 7 of Posthumous Memoirs) comes from Leopardi, from his do "Dialogo di un islandese". Dante, even more, he is the basis of Esau e Jacó.

RA: You affirm, in Machado de Assis: A Literary Life (2015), that Machado created a philosophical world. How can we perceive this in his literary path?

KDJ: Benedito Nunes shows, in the essay I mentioned, that Machado is always philosophical, but, at the same time, he makes fun of philosophy, refusing to adopt any postulate. He prefers to consider the flow of ideas and their change, the adaptations through time.

RA: "He is a rational moralist in pursuit of wisdom through his world theater" (2015, p. xii). Could you comment this statement?

KDJ: Machado stages a Baroque world of the Empire and its social and psychological structures; he observes and criticizes Illuminist ideals, found in the world of reason, frequently making use of maxims and proverbs so much appreciated by the French, by the likes of Rochefoucauld, Diderot and La Fontaine.

RA: Machado's creation of a philosophical world could have any relation to Italian authors?

KDJ: I think it has more to do with the reading of Greeks.

RA: What is the Machadian "rhetoric of dissimulation and substitution"?

KDJ: Machado frequently writes out of symbolic objects that dissimulate the true object. They substitute, in this sense, a more discursive description of a determined situation.

RA: Also in the book, you argue that Machado wrote for deeply literary reasons. What reasons could these have been? Do they explain the choice of title for your book, "A Literary Life"?

KDJ: The title was not mine, it was my editor's. I would have called it "world theater". And I need to emphasize that the key word in the title is "Literary", not "Life", because it does not intend to be a biography. It intends to investigate the literary fundaments of Machado's way of thinking, which has much to do with vast readings, as well as with theater and opera, so important in his experience as a young man and also in his novels. 
RA: In your opinion, how is the relation between the Rio de Janeiro portrayed by Machado, so intrinsic to his works, and the European influences that are equally present in his books?

KDJ: I think Brazil is also a part of the "universal", I do not find that a very useful terminology. Is it not the case of thinking about the voyages that largely helped forming the Brazilian culture through time? The "here and there" of "Canção do Exílio" by Gonçalves Dias. It seems to be more of a case of symbiosis than a case of "influence", unless we believe in a Brazilian singularity, pre-Cabralian, which afterwards received "influences".

RA: Do you have a preference for the work of any of the Anglophone translators of Machado de Assis? Why?

KDJ: I still like Helen Caldwell's translations very much, but also the Posthumous Memoirs by William Grossman and Clotilde Wilson's Quincas Borba. There are new translations, but it would have been more interesting to translate works that have not been translated yet, instead of retranslating those that had already been translated.

RA: Can Machado de Assis be considered a literary influence beyond Lusophone frontiers? In what way?

KDJ: His work is having more impact, but it is spreading slowly. For example, Carlos Fuentes wrote Machado de la Mancha. There is now an excellent critique on Machado de Assis by Paul Dixon. And Harold Bloom did his part when he included Machado in the list of essential authors of Western literature. Recent criticism should be more publicized, and Machado is still to be included in the canon of comparative literature. Generally speaking, Machado is not sufficiently read.

RA: Machado de Assis is the most studied Brazilian author abroad, according to a survey performed by Itaú Cultural in 2013. Do you notice a strong academic interest in Machado's work in the United States?

KDJ: What does this mean, "the most studied"? There are only 11,000 students of Portuguese language in the US, which have a population of 300 million inhabitants. Some students have "heard about him", but few have read him, and I believe even less understood anything. Unfortunately, there still isn't a "strong" interest in Machado, or in any other Brazilian author.

Recebido em 26/09/2017

Aceito em 28/12/2017 